Supplement of Nat. Hazards Earth Syst. Sci., 20, 695-712, 2020

https://doi.org/10.5194/nhess-20-695-2020-supplement

(C) Author(s) 2020. This work is distributed under

the Creative Commons Attribution 4.0 License.

(c) (1)

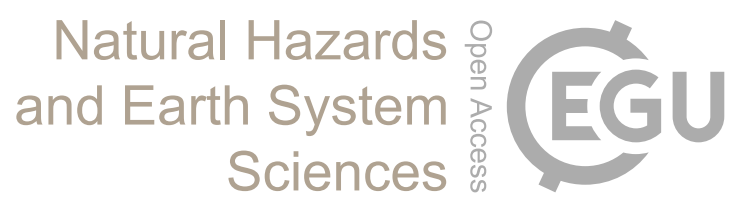

Supplement of

\title{
Global-scale drought risk assessment for agricultural systems
}

Isabel Meza et al.

Correspondence to: Isabel Meza (meza@ehs.unu.edu)

The copyright of individual parts of the supplement might differ from the CC BY 4.0 License. 


\section{Supplementary Material}
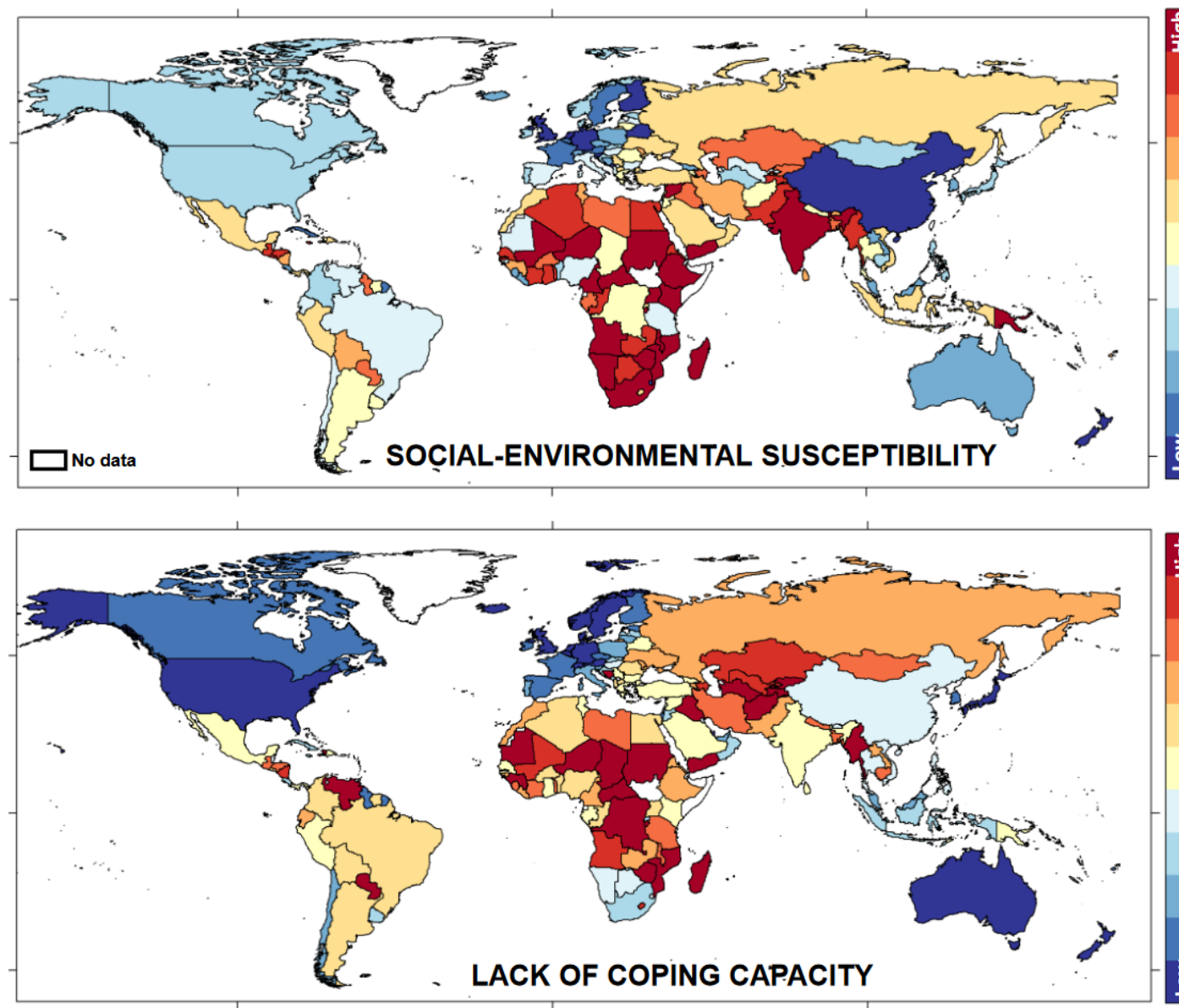

Figure S1. Social-environmental susceptibility and lack of coping capacity by country

Table S2. Final indicators for the vulnerability assessment and their respective code

\begin{tabular}{|l|l|}
\hline \multicolumn{1}{|c|}{ Social susceptibility (SOC_SUS) } & \multicolumn{1}{c|}{ CODE } \\
\hline Indicator & \multicolumn{2}{|c|}{} \\
\hline Prevalence of conflict/insecurity & C_STA1 \\
\hline Dependency ratio (Population ages 15-64 (\% of total population)) & E_DEP \\
\hline Unemployment, total (\% of total labor force) (national estimate) & E_EMP \\
\hline Share of GDP from agr., forestry and fishing in US\$ $\%$ ) & E_INC \\
\hline GINI index & E_INQ \\
\hline Proportion of population living below the national poverty line (\%) & E_POV \\
\hline Insecticides and pesticides used (ton/ha) & F_INPE \\
\hline Electricity production from hydroelectric sources (\% of total) & P_ELE \\
\hline Population using at least basic sanitation services (\%) & P_W\&S2 \\
\hline Access to improved water sources (\% of total population with access) & P_W\&S1 \\
\hline DALYs (Disability-Adjusted Life Years)(DALYs per 100,000, Rate) & S_DISP \\
\hline Literacy rate, adult total (\% of people ages 15 and above) & S_EDU \\
\hline Gender Inequality Index & S_GNDR \\
\hline Healthy life expectancy (HALE) at birth (years) & S_LEB \\
\hline Prevalence of undernourishment (\% of population) & S_NUT \\
\hline
\end{tabular}




\begin{tabular}{|c|c|}
\hline Rural population (\% of total population) & S_RUR \\
\hline \multicolumn{2}{|c|}{ Ecological susceptibility (ECO_SUS) } \\
\hline Average land degradation in GLASOD erosion degree & E_DEGR \\
\hline Terrestrial and marine protected areas (\% of total territorial area) & E_PROA \\
\hline Average soil erosion & E_SOIL2 \\
\hline Fertilizer consumption (kilograms per hectare of arable land) & F_FERT \\
\hline \multicolumn{2}{|l|}{ Lack of coping capacity (COP) } \\
\hline Saved any money in the past year (\% age $15+)$ & E_SAV \\
\hline Corruption Perception Index (CPI) & G_CORP \\
\hline Government Effectiveness: Percentile Rank & G_REP \\
\hline Total renewable water resources per capita (m3/inhab/year) & P_RW \\
\hline Travel time to cities $\leq 30 \mathrm{~min}$ (population) (\%) & P_TRNS \\
\hline Total dam storage capacity per capita. Unit: $\mathrm{m} 3 /$ inhab & P_WAT \\
\hline
\end{tabular}

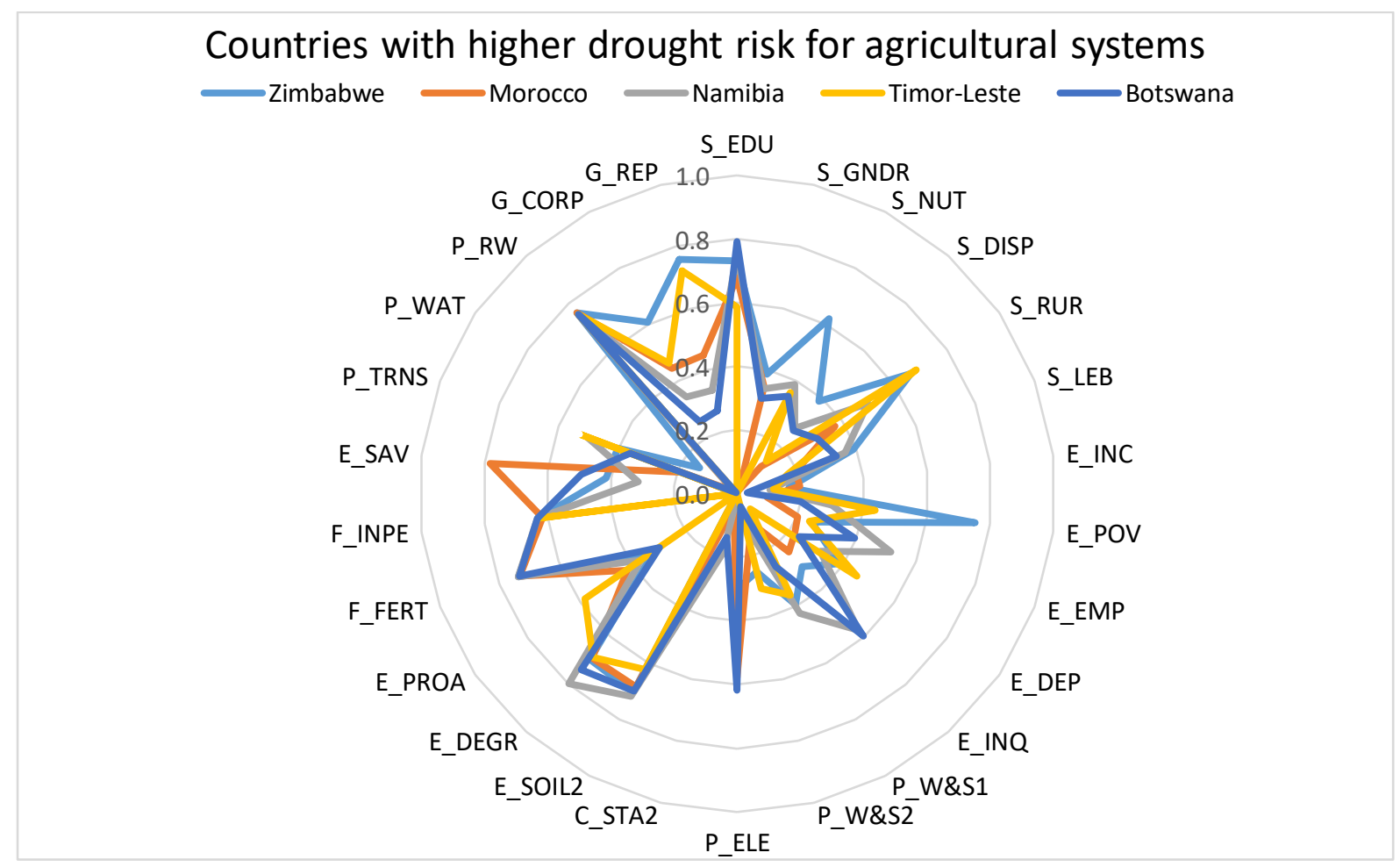

Figure S3. Weighted normalized vulnerability indicators scores for the five countries with highest drought risk for combined agricultural systems (irrigated and rain-fed) 


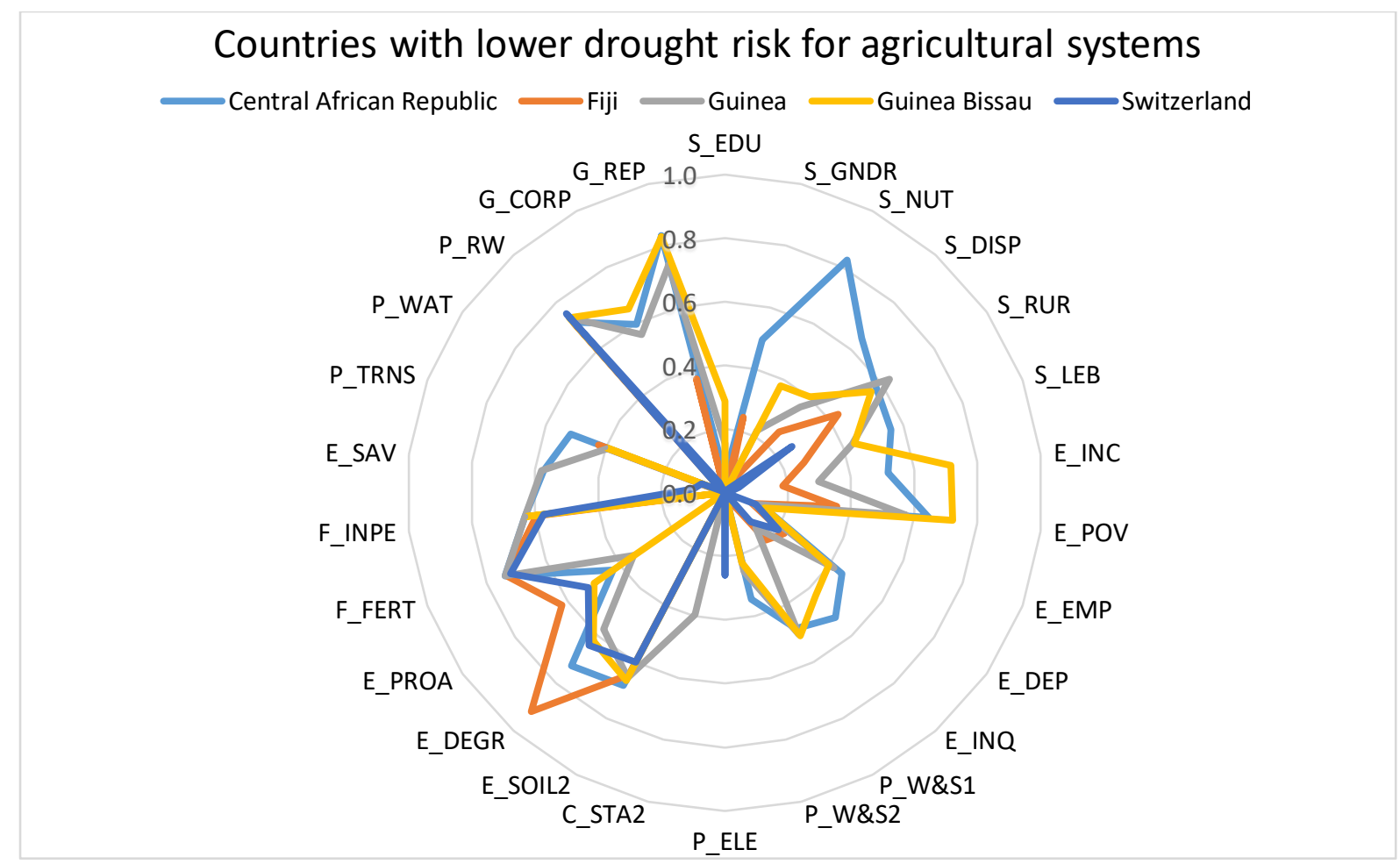

Figure S4. Weighted normalized vulnerability indicators scores for the five countries with lowest drought risk for combined agricultural systems (irrigated and rain-fed).

Table S5. Number of grid cells and harvested area of rainfed crops for the thresholds $10 \%, 20 \%$ and $50 \%$ for the deviation of the annual ratio AET/PET from the long-term median of the ratio AET/PET in different percentile classes. A percentile of 0.01 means that such an event can be expected every 100 years, a percentile of 0.5 means that such an event can be expected every 2 years.

10

20

50

\begin{tabular}{c|cc|cc|cc|} 
Percentile & Grid cells & $\begin{array}{c}\text { Harv. Area } \\
(\mathbf{\%})\end{array}$ & Grid cells & $\begin{array}{c}\text { Harv. Area } \\
(\mathbf{\%})\end{array}$ & Grid cells & $\begin{array}{c}\text { Harv. Area } \\
(\mathbf{\%})\end{array}$ \\
$\mathbf{0}$ & 3997 & 7.15 & 11877 & 28.44 & 32265 & 91.80 \\
$<\mathbf{0 . 0 1}$ & 4611 & 8.47 & 13137 & 32.12 & 33280 & 94.14 \\
$<\mathbf{0 . 0 2}$ & 5450 & 10.85 & 14823 & 37.23 & 34172 & 96.26 \\
$<\mathbf{0 . 0 5}$ & 7730 & 17.17 & 19082 & 50.89 & 35639 & 98.94 \\
$<\mathbf{0 . 1 0}$ & 11115 & 26.62 & 24384 & 69.66 & 36495 & 99.76 \\
$<\mathbf{0 . 2 0}$ & 19119 & 51.09 & 31656 & 91.09 & 37095 & 99.96 \\
$<\mathbf{0 . 3 0}$ & 28461 & 81.17 & 35785 & 98.87 & 37241 & 100.00 \\
$<\mathbf{0 . 5 0}$ & 37195 & 99.96 & 37264 & 100.00 & 37265 & 100.00
\end{tabular}

